\title{
BOOK-TAX DIFFERENCES AND CAPITAL STRUCTURE
}

MARIANA TITOTO MARQUES

Universidade de São Paulo (USP), Monte Alegre - Ribeirão Preto - SP - Brazil.

SILVIO HIROSHI NAKAO

Universidade de São Paulo (USP), Monte Alegre - São Paulo - SP - Brazil.

PATRÍCIA DE SOUZA COSTA

Universidade Federal de Uberlândia (UFU), Santa Mônica - Uberlândia - MG - Brazil.

To cite this paper: Marques, M. T., Nakao, S. H., \& Costa, P. de S. (2017). Book-tax differences and capital structure. Revista de Administração Mackenzie, 18(6), 177-200. doi 10.1590/1678-69712017/ administracao.v18n6p177-200 


\section{ABSTRACT}

Purpose: Thus, the purpose of this study is to verify the relationship between BTD, indebtedness and the cost of capital of Brazilian public companies before and after the adoption of IFRS.

Originality/value: The relation between book-tax differences (BTD) and accounting information quality is not a consensus in the literature. This relation can be empirically observed by means of the structure and the cost of capital, due to the related information asymmetry. However, a way to observe this relation more clearly is by means of changes and various economic environments.

Design/methodology/approach: The methodology involved panel data analysis from a sample of 1,079 observations for the period of 2005 to 2015.

Findings: The results lead to the conclusion that a higher BTD, and thus, lower book-tax conformity, represents higher accounting information quality because lower indebtedness is related to lower informational asymmetry. The results suggest that creditors and investors have different demands for reported information quality and that the volume of capital from investors is more relevant than the level of risk perceived by them.

\section{KEYWORDS}

Book-tax differences. Debt level. IFRS adoption. Indebtedness. Equity cost.

\section{INTRODUCTION}

The main cost of a bigger link between financial and fiscal accounting is the loss of relevance of accounting information for the stock market (Hanlon, Maydew, \& Shevlin, 2008). The level of this link, called book-tax conformity, 
can be measured by the difference between the book and tax income (book-tax differences - BTD). Thus, the lower the BTD, the lower the quality of earnings and, consequently, the greater the asymmetry of information.

On the other hand, Desai (2005) and Whitaker (2005) found out that, when BTD decreases, the quality of accounting information increases, and there is a consequent reduction in information asymmetry, due to the discretionary capacity of the managers. It is thus perceived that the relationship between BTD and the quality of accounting information is not a consensus in the literature.

One of the ways to empirically verify the issue is by observing the structure and the cost of capital. The primary concerns of creditors are whether the value of the company's assets is sufficient to cover the liabilities (Black \& Scholes, 1973) and whether the company has sufficient current and future cash flow to meet its obligations (Jensen \& Meckling, 1976). The creditors are probably less concerned about the quality loss of earnings which results in low BTD level - than investors (Easton, Monahan, \& Vasvari, 2009). In fact, they may prefer an accounting system that is closer to cash-basis because they do not participate in the company's future growth (Blaylock, Gaertner, \& Shevlin, 2017).

In addition, the pecking order theory predicts that in the presence of asymmetry of information between managers and shareholders, companies that need external financing will choose instruments with lower risk instead of riskier ones (issuance of shares) (Myers, 1984).

An empirical observation in this direction was made by Blaylock et al. (2017), which identified that, in the presence of major book-tax conformity, companies replace financing through the issuance of shares with creditors' financing. This survey was conducted with a sample of American companies, with non-legalistic origins (common law). In countries of this origin, BTD tends to be higher than in the countries of legalistic origin (civil law), since they have more developed capital markets and as a result, companies have less reliance on debt (Niyama, 2005). Guenther and Young (2000) identified that German companies tend to have less BTD than American companies because of the country's loyalist origins.

However, a way to observe the relationship between BTD and structure and cost of capital more clearly and as a result, the quality of the accounting information, is by observing the changes and/or economic environments. The changes allow the observation of effects as if they were an experiment. A change, such as the adoption of the International Financial Reporting Standards (IFRS), is a factor that should reduce informational asymmetry, 
thereby increasing BTD. The observation of different economic environments can confirm or expand the theory while considering new aspects. In a legalistic environment, one must expect a significant further increase of BTD and the consequent reduction in information asymmetry, given the reduction of tax legislation and corporate interference.

It is expected that, in Brazil, the adoption of IFRS has led to an increase of BTD in a larger proportion than in non-legalistic countries, where the essence over form already existed (Costa \& Lopes, 2015). The promulgation of Law No. 11.638 (2007) made the adoption of IFRS mandatory in Brazil, which assumes unlinking of financial and tax accounting. Consequently, it is expected BTD ascertained by Brazilian companies to expand after the adoption of IFRS, basically due to the increase of temporary differences. For example, impairment losses and fair value measurements should result in higher BTDs because the amounts recorded in financial statements will be taxed only when the asset is sold.

Considering that there were no material changes in the Brazilian tax legislation in this period, the change provided by the adoption of IFRS and the legalistic origin represent a set of factors that are favorable to the examination of the relationship between BTD and structure and cost of capital.

Thus, the research problem is: what is the effect of the indebtedness and cost of equity on the BTD level with the adoption of IFRS? The purpose of this study is to verify the effect of the indebtedness and cost of capital in BTD of Brazilian public companies before and after the adoption of IFRS.

For that, by a panel data, 1,079 observations of Brazilian public companies were analyzed for the periods from 2005 to 2007 and 2010 to 2015.

The results of this study may contribute to the accounting and finance literature, insofar as it links the informational gain of the adoption of IFRS in Brazil through BTD, given the previous book-tax conformity, with the level of informational asymmetry and the risk expressed by the indebtedness and the cost of equity. Most studies in these areas consider only the effects of taxes on the capital structure (Graham, 2002). This work extends the study of Blaylock et al. (2017), using BTD as a book-tax conformity measure and examining the change of accounting standards in a legalistic environment.

The results may be particularly relevant for standardized and regulators in assessing the costs and benefits of increasing book-tax conformity. In a recent publication, President Barack Obama suggested an increased binding between financial and tax accounting (Treasury, 2012). However, this could affect the quality of accounting information and consequently, increase the cost of capital and affect the capital structure, increasing indebtedness. 


\section{LITERATURE REVIEW AND DEVELOPMENT OF HYPOTHESES}

\subsection{Adoption of IFRS and BTD}

The difference between book income, calculated in accordance with accounting standards, and the taxable income, whose objective is tax collection, is called book-tax differences (BTD) in the literature (Hanlon \& Heitzman, 2010). Financial and fiscal accounting have had a historical strong link in Brazil, either by the obligation to calculate taxes through adjustments in the accounting income or by the existence of economic incentives for the use of similar criteria for the recognition and measurement of events for both purposes (Braga, Filho, \& Barros, 2014), which is called book-tax conformity in literature (Hanlon et al., 2005).

In 2007, Law 11.638/07 was promulgated in Brazil, forcing public companies to adopt the International Financial Reporting Standards (IFRS). The adoption of IFRS in Brazil assumes the untying between financial and tax accounting, which suggests that companies will have greater incentives to disclose accounting reports. Additionally, with this separation, the use of the Taxable Income Calculation Registry (Livro de Apuração do Lucro Real LALUR) should generate more BTD. For example, according to CPCs 01 and 46 , respectively, impairment losses and fair value adjustments must be recognized immediately at the time they occur in income, which is not for tax purposes. This divergence generates a temporary difference that is recorded through an addition (if it is a loss) or exclusion (if it is a gain) entry in LALUR. Thus, at the time of selling or writing off an asset, the loss/gain value should be added/excluded.

However, there is no consensus in the literature about the direct relationship between adoption of IFRS, BTD increase and the consequent quality increase of accounting information. Ball (2006) notes that a higher accounting standard like IFRS will not necessarily translate into higher quality disclosure because there are also political, economic and cultural forces influencing the quality of the reports. Studies of Ball, Kothari, and Robin (2000) and Burgstahler, Hail, and Leuz (2006) suggest a limited role of the international standards in determining the quality of the accounting reports and even highlight the relevance of the incentives behind the process of disclosure of financial statements.

According to Osma and Pope (2011), standards set by means of principles have a greater trend to offer a larger number of accounting choices, and 
thus, the heterogeneity of choices will be strengthened by the flexibility of IFRS. Corroborating, Daske, Hail, Leuz, \& Verdi (2013) claim that the companies present heterogeneity in the adoption of IFRS. The study, which verified the liquidity effects and the cost of capital of foreign companies that voluntarily adopted the standards, confirmed the hypothesis that there is heterogeneity from the adoption of IFRS because companies show differences in reporting incentives.

Thus, the adoption of standards alone may not be sufficient to guarantee an improvement in the quality of accounting information, given the possible presence of heterogeneity and flexibility of accounting choices by Brazilian companies. Therefore, differences in the quality of accounting information must be observed even after the convergence process is finalized, since quality is the result of the firm's institutional apparatus, which includes the country's legal and political systems (Rezaee, Smith, \& Szendi, 2010), as well as other incentives for information disclosure; some examples are: tax system, capital structure, ownership structure, and the level of development of the capital market (Osma \& Pope, 2011).

IFRS was developed in an environment where a developed and investor-oriented corporate governance model prevails (Hung \& Subramanyam, 2007), while in Brazil, the model has historically been oriented towards creditors (Lopes \& Walker, 2008). Therefore, it is considered that Brazil has a civil law tradition, or Roman law, while the international standards were created under a common law tradition, or Customary law (Ball, Robin, \& Wu, 2003). According to La Porta, Lopez-de-Silanes, Shleifer, \& Vishny (1998), in countries that follow the Roman law tradition, the investor's protection is weaker than in countries with Customary law tradition, with also lower enforcement (compliance with standards). Thus, when the investor protection is low, the market shows a stock concentration (La Porta et al., 1998), which is the reality in Brazil. Therefore, as we analyze the characteristics of the Brazilian institutional environment, it is possible to think that companies have low incentives to disclose their financial statements.

\subsection{Capital structure and BTD}

CPC 00 (CPC, 2011) sets the objective of financial reports for two groups (investors and creditors). This approach can be explained by the fact that companies have basically two ways of obtaining funds: through debt or by issuing shares (Damodaran, 2002). According to the so-called Pecking Order Theory (POT), firms make their decisions when they seek funds based on the following hierarchy: first, they prioritize retained earnings, then debt, 
and finally, by issuing shares (Myers \& Majluf, 1984). In this context, the capital structure may influence the quality of the information because companies with different financing needs have different incentives to the information disclosure process. That's because shareholders and creditors use different means to reduce their levels of informational asymmetry.

According to Martins, Martins, \& Martins, (2007), the creditors have greater access to information when compared to investors, especially the minority investors. According to these authors, in the process of taking credit, they get the information they want, allowing, therefore, to visualize the evolution of the company's assets better. So, they do not depend only on the balance sheets that are disclosed by companies to make their decisions. On the other hand, there are the investors that contribute to the equity of the company. This group requires high-quality information because they are mainly based on financial statements to make decisions concerning investments (Dalmácio \& Rezende, 2008).

Blaylock et al. (2017) argue that reducing the quality of earnings will result in an increase of informational asymmetry since the book-tax conformity will lead to an increase in financial leverage. Since the creditors mainly worry whether the value of the assets will be sufficient to cover the liabilities and whether the company has current and future cash flow to honor its obligations, they're probably less concerned about the loss of earnings quality in an environment of low BTD than investors.

Companies probably respond to informational quality loss (derived from the informational asymmetry) resulting from the reduction of BTD using more debt in their capital structures (Blaylock et al., 2017). In this line of thought, after the adoption of IFRS, the following is expected: reduction of the book-tax conformity, BTD, reduction of informational asymmetry, increase the quality of accounting information, reduction of financial leverage and the cost of equity and debt. IFRS are considered higher quality accounting standards because they prioritize the economic essence of the legal form, the reliable representation and the relevance of accounting information for the investor's decision-making process (Bowrin, 2008). In addition, the adoption of IFRS involves the application of responsible subjectivism in the process of accounting choices, which is not in line with the interference of tax legislation in accounting standards (Costa \& Lopes, 2015).

Therefore, assuming that a higher volume of BTD means a greater alignment of the accounting practices of the companies with the IFRS and based on the studies that indicate that IFRS are associated with better information quality, we can infer that if the pressure of investors for quality 
information is higher, companies with lower level of indebtedness present higher BTD after the adoption of IFRS in Brazil. The following research hypothesis is then formulated:

$H_{1}$ Brazilian listed companies with lower debt level have a higher level of BTD after the adoption of IFRS.

On the other hand, it is possible that the proportion of equity or debt does not significantly affect the quality of information if the investors' or creditors' demand for high-quality information is similar, or if the company that provides the information is indifferent to the capital structure when providing better quality information, without prioritizing the investor or the creditor.

Companies with lower capital costs may have less difficulty in obtaining investors who invest in them, especially if there is a higher quality of information from the point of view of information demand. However, from the point of view of the information supply, it is possible that the cost of equity does not significantly affect the quality of the information if it does not significantly influence the company's effort to provide better information to investors.

The second research hypothesis is then formulated:

$\mathrm{H}_{2}$ Brazilian listed companies with a lower cost of equity do not present a higher level of BTD after the adoption of IFRS.

\section{METHODOLOGY}

The research sample is composed of Brazilian nonfinancial public companies with shares traded on BM\&FBovespa. The consolidated statement data was taken from the Economática ${ }^{\circledR}$ database. The chosen period was from 2005 to 2015, except for the years of 2008 and 2009. The justification for choosing this period is the promulgation of Law No. 11.638 (2007), which has been required since the 2008 financial statements. However, the years 2008 and 2009 were impacted by the RTT, and therefore, there is no full adoption of the new rules. Another reason for the exclusion of the period was the global financial crisis in 2008, which could jeopardize the cost of equity.

Companies with passive or negative equity were excluded, as they could affect the calculation of the debt and the cost of capital, according to Teixeira, Nossa, \& Funchal (2011) (Chart 1). Observations with a negative result 
before income tax were excluded, according to the justifications presented by Hanlon (2005, p. 144): "[...] deferred tax assets, changes which can obscure the effects of 'true' book-tax differences in the deferred tax expense account". Besides that, the missing data for calculating BTD, the data from the year 2004 (used for calculation of lagged variables), and the companies that did not have data for at least 3 consecutive years before and after the adoption of IFRS were excluded from the sample. The final sample comprises 1,079 observations.

\section{(Chart 1)}

RESEARCH SAMPLE

\begin{tabular}{lc}
\hline & Number of observations \\
\hline Initial sample & 5.676 \\
\hline (-) companies with negative liabilities or net liabilities & -549 \\
\hline (-) companies with negative book income & -1.041 \\
\hline$(-)$ missing data for BTD & -1.366 \\
\hline$(-)$ year 2004 & -183 \\
\hline$(-)$ years 2008 and 2009 & -1.214 \\
\hline$(-)$ 3 consecutive years & -244 \\
\hline (=) Final sample: & 1.079 \\
\hline
\end{tabular}

Source: Elaborated by the authors.

The model tested in this research is shown in Equation 1.

$$
B T D_{i t}=\beta_{1} I N D_{i t}+\beta_{2} C E_{i t}+\beta_{3} R O A_{i t}+\beta_{4} S_{I Z E_{i t}}+\beta_{5} P P E_{t}+e_{i t} .
$$

Where:

BTD Difference between the Net Income Before Taxes (NIBT) and the taxable income (TI) divided by the lagged total assets (TA). Taxable income is the result of dividing the income tax expense of the period by the maximum tax rate $(34 \%)$.

IND Index of indebtedness, the result of dividing the total liabilities (L) by the equity (E) divided by the lagged total assets.

$C E \quad$ Cost of equity, calculated by Equation 2 .

ROA Net income (NI) divided by the lagged total assets. 
SIZE Natural logarithms of the total asset.

$P P E \quad P P \& E$ divided by the lagged total assets.

It should be noted that the calculation of the taxable income (the result from dividing the income tax expense of the period by the maximum tax rate of $34 \%$ ) represents an approximation since this information is not included in the financial statements. For this calculation, it would be necessary to make adjustments of additions, exclusions and eventual offsetting of tax losses. The maximum tax rate used was $34 \%$, which corresponds to the sum of income tax, additional income tax, and social contribution. It should be noted that the use of this rate has certain limitation, since $10 \%$ of it corresponds to the additional income tax for a legal entity that, according to article 542 of RIR/99, affects only the portion of the taxable income that exceeds the amount resulting from multiplication of $\mathrm{R} \$ 20,000.00$ by the number of months in the calculation period. Thus, some analyzed companies may not fit this criterion. However, Lev and Nissim (2004) assert that errors caused by using $34 \%$ income tax rate did not significantly affect the calculation of BTD.

The variable IND represents the level of indebtedness. This index has the function to relate the two major sources of funds of the company: debt and equity. It is an indicator of risk or dependence on debt. A negative relationship between the debt and BTD is expected.

For the calculation of the cost of equity (CE), we used the Capital Asset Pricing Model (CAPM). We chose the methodology of Louza, Cunha, Iara, and Rech (2014) for the Brazilian reality, in which besides being necessary to add the country risk in the original equation, we also use indexes of the American market because they are more stable. Thus, Equation 2 illustrates the formula for the calculation of the cost of equity (CE) appropriate to the Brazilian context:

$$
C A P M=R f+\beta(R m-R f)+\alpha \mathrm{BR}
$$

$\mathrm{Rf}$ (risk-free) is the risk-free rate. According to what Brigham, Gapenski, and Ehrhardt (2001) recommend, we opted for the profitability of long-term US government bonds (treasury bonds, or t-bonds) to ensure consistency with the maturity of the investment to be analyzed. $\beta$ is the beta of companies. According to Louza et al. (2014), we used the unweighted average betas of US firms that are comparable with the Brazilian sectors. Later, the betas were leveraged through equation (3): 


$$
\beta l=\beta \mu\left[1+(1-t) x\left(\frac{D}{E}\right)\right] .
$$

$\beta l$ is the leveraged beta; $\beta \mu$ is the unleveraged beta, the unleveraged beta of each American sector compared to the Brazilian; $t$ is the current tax rate, which is $34 \%$; $D$ is the debt and $E$ is equity. $\mathrm{Rm}$ (market risk) is market risk rate. The return of S\&P 500 was used as a return proxy of the American market, as suggested by a large part of the literature, given its representativeness (Damodaran, 1999, 2002; Louza et al., 2014).

The variable $\alpha \mathrm{BR}$ from Equation 2 represents the country risk, the additional remuneration paid by Brazilian bonds in relation to the t-bonds and it is "seen as a spread by default risk (Louza et al., 2014). For the Brazilian bond, we used c-bond (capitalization bond) that is admitted to having greater liquidity, in addition to being freely transacted in the international market. A negative relationship is expected between the cost of equity and BTD.

The variables ROA, SIZE, and PPE are control variables used to examine the effects of profitability, firm size and the level of detention of companies in BTD, respectively. According to Koubaa and Anis (2015) and Fonseca and Costa (2017), the most profitable companies can expand the deductions and tax credits more effectively to benefit from tax exemptions and to reduce the taxable income in an attempt to reduce the taxes to be paid, thus expanding BTD. Costa and Lopes (2015) also found a positive relationship between profitability (ROA) and BTD.

The total asset logarithm (SIZE) is a proxy used to measure the size of the firm. According to Costa and Lopes (2015) and Fonseca and Costa (2017), a negative relationship between the size of the company and BTD is expected, since large companies tend to comply more with tax regulations in order to avoid regulatory oversight, which would make for greater booktax conformity. On the other hand, large companies may seek to obtain a better quality of accounting information to attract more investors, using more criteria of reliable representation in the use of accounting choices and responsible subjectivism, inherent to the adoption of IFRS in corporate accounting (Barth, Landsman, \& Lang, 2008). As a result, the size of companies can be positively related to BTD after the adoption of IFRS.

The investment in property, plant, and equipment (PPE) is positively related to BTD, since the accounting criteria related to the recognition of depreciation and the recoverable amount of the asset in the corporate accounting are, for the most part, different from those permitted by the tax legislation, which may increase BTD. 
Table 1 shows a summary of the study variables shown in Equation 1 and the expected signals.

\section{(Table 1)}

SUMMARY OF THE EXPECTED STUDY VARIABLES AND SIGNALS

\begin{tabular}{|c|c|c|c|c|}
\hline Variable & Type & Formula & Sign Expected & Literature \\
\hline BTD & D & $\frac{N I B T_{i, t}-T I_{i}}{T A_{i t}}$ & & \\
\hline IND & । & $\frac{L_{i, t}}{E_{i, t}}$ & - & \\
\hline CE & । & $R f+\beta(R m-R f)+\alpha_{B R}$ & - & \\
\hline$R O A$ & C & $\frac{N \mathrm{~N}_{i, t}}{T \mathrm{~A}_{i, t-1}}$ & + & $\begin{array}{l}\text { Costa \& Lopes (2015), Koubaa } \\
\text { \& Anis (2015), Blaylock et al. } \\
\text { (2017), Fonseca \& Costa } \\
\text { (2017) }\end{array}$ \\
\hline SIZE & c & $\ln (T A i, t)$ & $\begin{array}{l}- \\
\text { before and + after } \\
\text { adoption of IFRS }\end{array}$ & $\begin{array}{l}\text { Tang (2006), Costa \& Lopes } \\
\text { (2015), Koubaa \& Anis (2015), } \\
\text { Fonseca \& Costa (2017) }\end{array}$ \\
\hline$P P E$ & C & $\frac{P P E_{i, t}}{T A_{i, t-1}}$ & + & $\begin{array}{l}\text { Costa \& Lopes (2015), Koubaa } \\
\text { \& Anis (2015), Blaylock } \\
\text { et al. (2017), Fonseca \& } \\
\text { Costa (2017) }\end{array}$ \\
\hline
\end{tabular}

Note: D - dependent; I - interest; C - control; BTD - difference between the NIBT and TI divided by the TA; NIBT - Net Income Before Taxes; $\mathrm{TI}$ - income tax expense for the period divided by the maximum tax rate of 34\%; TA - lagged total assets; IND - index of indebtedness; L - total liabilities; E - equity; CE - cost of equity; $R f$ - risk-free rate; $\beta$ - beta of companies calculated according to Equation 3; Rm- market risk rate; $x B R$ - country risk; ROA - return on assets; $\mathrm{NI}$ - net income; SIZE - natural logarithm of total assets; PPE- Total fixed assets divided by the lagged total assets.

Source: Elaborated by the authors.

The template specified in Equation 1 was tested for three distinct periods: 1) before the adoption of IFRS - 2005 to 2007; 2) after the adoption of IFRS - 2010 to 2015 and 3) for the full period - 2005 to 2015 (except 2008 and 2009). The purpose is to identify whether the relationship between indebtedness, cost of equity and BTD are similar in these periods.

The three specifications for panel data were tested through the Stata $14^{\circledR}$, software: pooled, fixed effects and random effects. For the definition of the most suitable model for the data of this research, the tests of Chow, Breusch, and Pagan and Hausman were used. 


\section{RESULTS}

The descriptive statistics of the research sample is presented in Chart 2. The average BTD increased from 0.027 before the adoption of IFRS to 0.033 after this period. This result suggests a reduction in the link between corporate and tax accounting, which was expected with the adoption of IFRS. To verify whether this increase in BTD is significant, the mean test was performed, according to Chart 2.

\section{(Chart 2)}

DESCRIPTIVE STATISTICS

\begin{tabular}{|c|c|c|c|c|c|c|c|}
\hline & Variables & Notes & Mean & $\begin{array}{l}\text { Standard } \\
\text { Deviation }\end{array}$ & Minimum & Median & Maximum \\
\hline \multirow{6}{*}{$\begin{array}{l}\text { Before the adoption } \\
\text { of IFRS - } 2005 \text { to } \\
2007\end{array}$} & BTD & 370 & 0,027 & 0,046 & $-0,031$ & 0,013 & 0,143 \\
\hline & IND & 370 & 1,531 & 1,196 & 0,112 & 1,232 & 4,586 \\
\hline & $C E$ & 370 & 0,190 & 0,228 & $-0,161$ & 0,116 & 0,833 \\
\hline & $R O A$ & 370 & 0,088 & 0,060 & 0,018 & 0,076 & 0,254 \\
\hline & SIZE & 370 & 14,066 & 1,718 & 11,129 & 14,118 & 17,436 \\
\hline & $P P E$ & 370 & 0,450 & 0,268 & 0,000 & 0,432 & 0,876 \\
\hline \multirow{6}{*}{$\begin{array}{l}\text { After the adoption } \\
\text { of IFRS - } 2010 \text { to } \\
2015\end{array}$} & BTD & 709 & 0,033 & 0,044 & $-0,031$ & 0,023 & 0,143 \\
\hline & IND & 709 & 1,472 & 1,160 & 0,112 & 1,259 & 4,586 \\
\hline & $C E$ & 709 & 0,225 & 0,242 & $-0,161$ & 0,195 & 0,833 \\
\hline & $R O A$ & 709 & 0,091 & 0,064 & 0,018 & 0,073 & 0,254 \\
\hline & SIZE & 709 & 14,768 & 1,752 & 11,129 & 15,039 & 17,436 \\
\hline & $P P E$ & 709 & 0,249 & 0,257 & 0,000 & 0,189 & 0,876 \\
\hline \multirow{6}{*}{ Total } & BTD & 1.079 & 0,031 & 0,045 & $-0,031$ & 0,021 & 0,143 \\
\hline & IND & 1.079 & 1,492 & 1,172 & 0,112 & 1,246 & 4,586 \\
\hline & $C E$ & 1.079 & 0,213 & 0,238 & $-0,161$ & 0,179 & 0,833 \\
\hline & $R O A$ & 1.079 & 0,090 & 0,063 & 0,018 & 0,074 & 0,254 \\
\hline & SIZE & 1.079 & 14,527 & 1,771 & 11,129 & 14,694 & 17,436 \\
\hline & $P P E$ & 1.079 & 0,318 & 0,277 & 0,000 & 0,279 & 0,876 \\
\hline
\end{tabular}

Note: D - dependent; I - interest; C - control; BTD - difference between the NIBT and TI divided by the TA; IND - index of indebtedness; CE - cost of equity; ROA - return on assets; SIZE - natural logarithm of total assets; PPE - Total fixed assets divided by the lagged total assets. 
The first step was to perform the normality and average tests (Chart 3). The p-values for the Kolmogorov-Smirnov and Shapiro-Wilk tests were 0.000, wherefore we can reject the null hypothesis, concluding that the data distribution is not normal. Given this fact, we used the Mann-Whitney nonparametric test to identify whether the mean of the BTD samples before and after the adoption of IFRS was drawn from populations with the same means. The significance level of the test, being below 0.05 for BTD, suggests that the means of this variable are different before and after the adoption of IFRS. Thus, it can be stated that the BTD, on average, increased after the adoption of IFRS, i.e., the book-tax conformity has decreased after the adoption of the international standards.

\section{(Chart 3)}

TEST OF AVERAGE BTD - BEFORE AND AFTER THE ADOPTION OF IFRS

\begin{tabular}{ccccccc} 
& \multicolumn{4}{c}{ Test of Normality } & \multicolumn{2}{c}{ Mann-Whitney } \\
\cline { 2 - 5 } Variable & \multicolumn{2}{c}{ Kolmogorov-Smirnov } & \multicolumn{2}{c}{ Shapiro-Wilk } & \multicolumn{2}{c}{} \\
\cline { 2 - 6 } & Statistics & $p$-value & Statistics & $p$-value & $z$ & sig \\
\hline \multirow{2}{*}{ BTD } & 0.507 & 0.000 & 0.011 & 0.000 & -3.253 & 0.001 \\
\hline
\end{tabular}

Source: Elaborated by the authors.

The correlations between the study variables are presented in Chart 4 . It is noticed that BTD and indebtedness (IND) are negatively associated with before and after the adoption of IFRS, but this Association is significant at $1 \%$ level only after the period of adoption. The cost of equity (CE) showed no significant correlation with BTD. Thus, the results suggest at first that IND and CE are not related to BTD before the adoption of IFRS and indebtedness is negatively related to BTD after the adoption of those standards.

\section{(Chart 4)}

\section{CORRELATIONS}

Panel A - Before the adoption of IFRS

\begin{tabular}{ccccccc} 
& $B T D$ & IND & CE & ROA & SIZE & PPE \\
\hline BTD & 1 & & & & \\
\hline IND & -0.064 & 1 & & & \\
\hline$C E$ & 0.038 & $0.259^{\star \star \star}$ & 1 & & \\
\hline
\end{tabular}




\section{(Chart 4 (conclusion))}

CORRELATIONS

\begin{tabular}{|c|c|c|c|c|c|c|}
\hline \multicolumn{7}{|c|}{ Panel A - Before the adoption of IFRS } \\
\hline & $B T D$ & IND & $C E$ & $R O A$ & SIZE & PPE \\
\hline$R O A$ & $-0.113^{\star \star}$ & $0.096^{\star}$ & 0.007 & 1 & & \\
\hline SIZE & -0.015 & $0.443^{\star \star \star *}$ & $0.114^{\star \star}$ & $0.090^{*}$ & 1 & \\
\hline PPE & -0.019 & 0.090 & 0.051 & $0.115^{\star *}$ & $0.207^{\star * \star}$ & 1 \\
\hline \multicolumn{7}{|c|}{ Panel B - After the adoption of IFRS } \\
\hline BTD & 1 & & & & & \\
\hline IND & 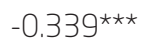 & 1 & & & & \\
\hline$C E$ & -0.062 & $0.241^{\star \star \star}$ & 1 & & & \\
\hline$R O A$ & $0.131^{\star \star \star}$ & 0.004 & 0.001 & 1 & & \\
\hline SIZE & -0.059 & $0.462^{\star \star \star}$ & $0.132^{\star \star \star}$ & $0.069^{*}$ & 1 & \\
\hline PPE & -0.049 & $-0.094^{\star \star}$ & 0.004 & -0.017 & 0.026 & 1 \\
\hline \multicolumn{7}{|c|}{ Panel C - Complete sample } \\
\hline BTD & 1 & & & & & \\
\hline IND & $-0.241^{* \star *}$ & 1 & & & & \\
\hline$C E$ & -0.023 & $0.245^{\star * \star}$ & 1 & & & \\
\hline$R O A$ & $0.050^{\star}$ & 0.034 & 0.004 & 1 & & \\
\hline SIZE & -0.029 & $0.443^{\star \star \star}$ & $0.136^{\star \star \star}$ & $0.079^{\star \star \star}$ & 1 & \\
\hline PPE & $-0.059 * \star$ & -0.018 & -0.005 & 0.017 & 0.017 & 1 \\
\hline
\end{tabular}

Note: D - dependent; I- interest; C - control; BTD - difference between the NIBT and TI divided by the TA; IND - index of indebtedness; CE - cost of equity; ROA - return on assets; SIZE - natural logarithm of total assets; PPE - Total fixed assets divided by the lagged total assets.

Source: Elaborated by the authors.

After the correlations were made, we started the analysis of panel data. The first step was to identify which model was best suited to the data of this research (fixed, random or pooled). The results for Chow, Breusch and Pagan and Hausman are shown in Chart 5. The results suggest that the most appropriate model is the fixed effects model. 


\section{(Chart 5)}

BREUSCH AND PAGAN, HAUSMAN AND CHOW TESTS

\begin{tabular}{cccccc}
\hline Panel & Statistics & Breusch and Pagan & Hausman & Chow & Model \\
\hline \multirow{2}{*}{ BTD } & Chi2 & 474,12 & 14,66 & 5,39 & \\
\cline { 2 - 5 } & Prob & 0,000 & 0,011 & 0,000 & \\
\hline
\end{tabular}

Source: Elaborated by the authors.

In this context, the results of the tests to the Equation 1, fixed effects, are highlighted in Chart 5. The F-test significant at $1 \%$ level shows that the proposed model is appropriate, i.e. at least one of the initially included explanatory variables is significant to explain the BTD behavior. The basic assumptions of the models were tested: Heteroscedasticity, normality, and multicollinearity. Through the Breusch-Pagan/Cook-Weisberg test, we could not observe the presence of heteroskedasticity ( $p$-value 0.000 ), still, all models were estimated with robust standard errors. The waste from the regressions showed normal distribution at 5\% significance level, according to the Shapiro-Francia test. The models tested in this research did not present too high VIF (Variance Inflation Factor) statistics for any explanatory variable (all less than 4), which suggests lack of multicollinearity of these variables.

Equation 4 was tested three times (Chart 6): 1) for the period of 2005-2007 - before the adoption of IFRS, 2) for the period of 2010-2015 after the adoption of IFRS; 3) for the whole period of 2005-2015 (except for the years of partial adoption, 2008 and 2009).

\section{(Chart 6)}

\section{RESULTS OF THE ESTIMATIONS FOR FIXED EFFECTS}

$$
B T D_{i t}=\beta_{1} I N D_{i t}+\beta_{2} C E_{i t}+\beta_{3} R O A_{i t}+\beta_{4} S I Z E_{i t}+\beta_{5} P P E_{i t}+e_{i t}
$$

\begin{tabular}{|c|c|c|c|c|c|c|c|c|c|}
\hline & \multicolumn{3}{|c|}{$\begin{array}{c}\text { Before the Adoption } \\
\text { of IFRS }\end{array}$} & \multicolumn{3}{|c|}{$\begin{array}{l}\text { After the Adoption of } \\
\text { IFRS }\end{array}$} & \multicolumn{3}{|c|}{ Total Period } \\
\hline & Coef. & $z$ & Sig. & Coef. & $z$ & Sig. & Coef. & $z$ & Sig. \\
\hline$\beta_{1}-$ IND & 0.002 & 0.44 & & -0.015 & -4.15 & 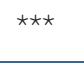 & -0.012 & -3.86 & $\star \star \star$ \\
\hline$\beta_{2}-C E$ & 0.006 & 0.87 & & 0.005 & 1.11 & & 0.005 & 1.25 & \\
\hline$\beta_{3}-\mathrm{ROA}$ & -0.073 & -1.89 & & 0.016 & 0.76 & & 0.027 & 1.03 & \\
\hline
\end{tabular}




\section{(Chart 6 (conclusion))}

RESULTS OF THE ESTIMATIONS FOR FIXED EFFECTS

\begin{tabular}{|c|c|c|c|c|c|c|c|c|c|}
\hline & \multicolumn{3}{|c|}{$\begin{array}{c}\text { Before the Adoption } \\
\text { of IFRS }\end{array}$} & \multicolumn{3}{|c|}{$\begin{array}{l}\text { After the Adoption of } \\
\text { IFRS }\end{array}$} & \multicolumn{3}{|c|}{ Total Period } \\
\hline & Coef. & $z$ & Sig. & Coef. & $z$ & Sig. & Coef. & $z$ & Sig. \\
\hline$\beta_{4}-\mathrm{SIZE}$ & -0.022 & -2.27 & $\star \star$ & 0.006 & 0.80 & & 0.007 & 1.98 & $\star \star$ \\
\hline$\beta_{5}-\mathrm{PPE}$ & 0.044 & 1.06 & & 0.006 & 0.23 & & 0.013 & 1.27 & \\
\hline$\alpha$ & 0.318 & 2.38 & $\star \star$ & -0.033 & -0.32 & & -0.059 & -1.17 & \\
\hline$F($ sig. $)$ & \multicolumn{4}{|c|}{$2,18^{\star \star \star}$} & \multicolumn{2}{|c|}{$3,83^{\star \star \star}$} & \multicolumn{3}{|c|}{$3,65^{\star \star \star}$} \\
\hline Number of observations & \multicolumn{4}{|c|}{370} & \multicolumn{2}{|r|}{709} & \multicolumn{3}{|c|}{1,079} \\
\hline Number of groups & \multicolumn{3}{|r|}{129} & \multicolumn{3}{|r|}{129} & \multicolumn{3}{|c|}{130} \\
\hline$R^{2}$ & \multicolumn{3}{|c|}{0,0535} & \multicolumn{3}{|c|}{0,0621} & \multicolumn{3}{|c|}{0,0486} \\
\hline
\end{tabular}

Note: D - dependent; I - interest; C - control; BTD - difference between the NIBT and TI divided by the TA; IND - index of indebtedness; CE - cost of equity; ROA - return on assets; SIZE - natural logarithm of total assets; PPE - Total fixed assets divided by the lagged total assets.

***, **, ** represent significance at the level of 1\%, 5\% and 10\%, respectively.

Source: elaborated by the authors.

The three regressions show relatively reduced $\mathrm{R}^{2}$, but they are all significant in the F-test at $1 \%$.

In the regression for the whole period (2005 to 2015), the variable of interest IND presents negative and significant coefficient at $1 \%$ level. The result suggests that indebtedness negatively affects $B T D$ throughout the period.

However, the analysis can be supplemented with the observation of the tests for the periods before and after the adoption of IFRS. The results presented in Chart 6 for the period prior to the adoption of these standards suggest that variables BTD and IND are not related because the variable coefficient IND does not present significant result. Meanwhile, the negative coefficient is significant at $1 \%$ level of variable IND for the period after the adoption of IFRS; this suggests that, during this period, the larger the BTD, the lower the indebtedness.

The coefficient of the variable cost of equity $(C E)$ showed no significance in any of the three tested periods (Chart 6).

The size control variable (SIZE) has a negative coefficient and significance at $1 \%$ in the period prior to the adoption of IFRS. This result corroborates 
those of previous studies (Costa \& Lopes, 2015; Koubaa \& Anis, 2015; Fonseca \& Costa, 2017). However, the coefficient signal of the variable SIZE became positive and nonsignificant after the adoption of these norms. Although the coefficient is not significant, the positive signal can be a sign of improvement of the quality of accounting information after the adoption of IFRS, as suggested by Barth et al. (2008).

The other control variables showed no significant coefficient at $1 \%$ level, which suggests that the ROA and PPE do not affect BTD. It was expected that a positive and significant relationship between these variables and BTD would occur.

Some additional tests were carried out for greater robustness of the results. First, companies with negative book income, negative $\mathrm{E}$ and negative liabilities were not excluded from the sample selection. Although there were theoretical justifications described in the Methodology section about these exclusions, tests were carried out to assess whether the fact that the company was not financially prosperous in the period of analysis would alter the results of the survey. In this case, the sample consisted of 2,324 observations. The results were similar to those presented in Chart 6 . That is, the signs and the significance of the variables of interest, indebtedness (IND) and equity (CE) continued the same as shown in Chart 6 . The significance of the variable ROA was the only one that has changed. The profitability (ROA) has a positive and significant relationship with the variable BTD.

The second test is related to the inclusion of the years 2008 and 2009 in the survey sample. The sample consisted of 2,137 observations. The only change in the result is also linked with the variable ROA, which became significant.

It is possible to notice that the relationship between BTD and the interest variables in this research (indebtedness and cost of capital) remained the same in all tests in this study, which may be an evidence of the robustness of the results.

\section{CONCLUSIONS}

The aim of this study was to verify the relationship between BTD, indebtedness and the capital cost of Brazilian listed companies before and after the adoption of IFRS, as a way to verify whether BTD represents or not the quality of accounting information. The survey sample comprised 1,079 
observations of Brazilian listed companies in the period from 2005 to 2007 (before the adoption) and from 2010 to 2015 (after the adoption).

According to the results described in the previous section in relation to the indebtedness, hypothesis $\mathrm{H}_{1}$, that Brazilian listed companies with lower indebtedness level have a higher level of BTD after adopting IFRS, cannot be rejected. For it to be rejected, the sign of the coefficient would have to be positive or not significant on the test with the data after the adoption of IFRS. Thus, in a legalistic environment, with accounting standard changes, companies with higher BTD had a higher level of equity in their capital structures.

This result leads to the conclusion that an increase in BTD, and thus lower book-tax conformity, represents a higher quality of accounting information since lower indebtedness is linked to lower information asymmetry. The result also refers to the notion that creditors have lower demand for information quality than investors.

However, the results regarding the cost of capital itself do not allow us to accept hypothesis $\mathrm{H}_{2}$, that Brazilian listed companies with a lower cost of equity do not have a higher level of BTD after adopting IFRS, as the signs of the coefficients of the corresponding variable were not significant.

This result suggests that the cost of equity does not significantly influence the company's effort to provide better quality information to investors, in a legalistic environment, with accounting standard changes. This indicates that the risk level perceived by investors is not an explanatory factor of the quality of information for investors.

These results suggest that creditors and investors have different demands for the quality of the disclosed information and that the volume of capital employed by investors is more relevant than the level of risk perceived by them.

The results of this study contribute to the literature, where the information gain through BTD, indebtedness, and cost of equity, in a legalistic environment with accounting standard changes, is verified. They can also contribute to the practice for evaluation of costs and benefits of increasing the book-tax conformity by standardized and regulators.

It is suggested other studies to be conducted in order to verify the relationship between BTD, information asymmetry and quality of accounting information. 


\section{REFERENCES}

Ball, R. (2006). International Financial Reporting Standards (IFRS): Pros and cons for investors. Accounting and Business Research, 36 (1), 5-27. doi 10.1080/ 00014788.2006.9730040

Ball, R., Kothari, S. P., \& Robin, A. (2000). The effect of international institutional factors on properties of accounting earnings. Journal of Accounting and Economics, 29(1), 1-51. 10.1016/S0165-4101(00)00012-4

Ball, R., Robin, A., \& Wu, J. S. (2003). Incentives versus standards: Properties of accounting income in four East Asian countries and implications for acceptance of IAS. Journal of Accounting and Economics, 36(1/3), 235-270. doi 10.1016/j.jacceco.2003.10.003

Barth, M. E., Landsman, W. R., \& Lang, M. H. (2008). International accounting standards and accounting quality. Journal of Accounting Research, 46(3), 467-498. doi 10.1111/j.1475-679X.2008.00287.x

Black, F., \& Scholes, M. (1973). The pricing of options and corporate liabilities. Journal of Political Economy, 81 (3), 637-654. doi doi.org/10.1086/260062

Blaylock, B., Gaertner, F. B., \& Shevlin, T. (2017). Book-tax conformity and capital structure. Review of Accounting Studies, 22 (2). doi 10.1007/s11142017-9386-2

Braga, R. N., Filho, J. M. D., \& Barros, P. H. (2014). A tributação como incentivo ao conservadorismo: Uma análise dos efeitos da alíquota efetiva dos tributos sobre o lucro e da book-tax diferences. Proceeding of the Seminários em administração (Semead), São Paulo, SP, Brazil, 15.

Brigham, E. F., Gapenski, L. C., \& Ehrhardt, M. C. (2001). Administração financeira: teoria e prática. São Paulo, SP: Atlas.

Burgstahler, D., Hail, L., \& Leuz, C. (2006). The importance of reporting incentives: Earnings management in European private and public firms. The Accounting Review, 81 (5), 983-1016. doi 10.2308/accr.2006.81.5.983

Comitê de Pronunciamentos Contábeis (2011). Pronunciamento Técnico CPC 00 - Estrutura Conceitual para Elaboração e Divulgação de Relatório Contábil-Financeiro. Retrieved from http://www.cpc.org.br/CPC/ Documentos-Emitidos/Pronunciamentos/Pronunciamento? $\mathrm{Id}=80$

Comitê de Pronunciamentos Contábeis (2010). Pronunciamento Técnico CPC 01 - Redução ao valor recuperável de ativos. Retrieved from http://www.cpc.org.br/CPC/Documentos-Emitidos/Pronunciamentos/ Pronunciamento? $\mathrm{Id}=2$ 
Comitê de Pronunciamentos Contábeis. (2012). Pronunciamento Técnico CPC 46 - Mensuração do valor justo. Retrieved from http://www.cpc.org. $\mathrm{br} / \mathrm{CPC} /$ Documentos-Emitidos/Pronunciamentos/Pronunciamento? $\mathrm{Id}=78$

Costa, P. S., \& Lopes, A. B. (2015). Implicações da adoção das IFRS sobre as booktax differences: O caso do Brasil. Germany: NEA.

Damodaran, A. (2002). Investment valuation: tools and techniques for determining the value of any asset. New York, Ny: John Wiley \& Sons.

Damodaran, A. (1999). Estimating Risk Parameters. Working Paper. Stern School of Business, New York.

Daske, H., Hail, L., Leuz, C., \& Verdi, R. (2013). Adopting a label: Heterogeneity in the economic consequences around IAS/IFRS adoptions. Journal of Accounting Research, 51 (3), 495-547. doi 10.1111/1475-679X.12005

Desai, M. (2005). The degradation of corporate profits. Journal of Economic Perspectives, 19(4), 171-192. doi 10.1257/089533005775196705

Easton, P., Monahan, S., \& Vasvari, F. (2009). Initial evidence on the role of accounting earnings in the bond market. Journal of Accounting Research, 47(3), 721-766. doi 10.1111/j.1475-679X.2009.00333.x

Fonseca, K. B. C., \& Costa, P. S. (2017). Fatores determinantes das booktax differences. Revista de Contabilidade e Organizações, 11 (29), 17-29. doi 10.11606/rco.v11i29.122331

Graham, J. R., \& Harvey, C. R. (2002). How do CFOs make capital budgeting and capital structure decisions. Journal of Applied Corporate Finance, 15(1), 8-23. doi 10.1111/j.1745-6622.2002.tb00337.x

Guenther, D., \& Young, D. (2000). The association between financial accounting measures and real economic activity: A multinational study. Journal of Accounting and Economics, 29(1), 53-72. doi 10.1016/S01654101(00)00013-6

Hanlon, M. (2005). The persistence and pricing of earnings, accruals and cash flows when firms have large book-tax differences. The Accounting Review, 80(1), 137-166. doi 10.2308/accr.2005.80.1.137

Hanlon, M., \& Heitzman, S. (2010). A review of tax research. Journal of Accounting and Economics, 50(2-3), 127-178. doi 10.2139/ssrn. 1476561

Hanlon, M., Laplante, S. K., \& Shevlin, T. J. (2005). Evidence for the possible information loss of conforming book income and taxable income. Journal of Law and Economics, 48(2), 407-442. doi 10.1086/497525 
Hung, M., \& Subramanyam, K. R. (2007). Financial statement effects of adopting international accounting standards: The case of Germany. Review of Accounting Studies, 12(4), 623-657. doi 10.2139/ssrn.622921

Jensen, M., \& Meckling, W. (1976). Theory of the firm: Managerial behavior, agency costs and capital structure. Journal of Financial Economics, 3(4), 305-360. doi 10.1016/0304-405X(76)90026-X

Koubaa, R. R., \& Anis, J. (2015). Book-tax differences: Relevant explanatory factors. International Journal of Accounting and Economics Studies, 3(2), 95-104. doi 10.14419/ijaes.v3i2.4717

La Porta, R., Lopez-de-Silanes, F., Shleifer, A., \& Vishny, R. W. (1998). Law and finance. Journal of Political Economy, 106(6), 1113-1155. doi 10.1086/ 250042

Lei $n$. 11.638, de 28 de dezembro de 2007. (2007). Altera e revoga dispositivos da Lei n. 6.404, de 15 de dezembro de 1976, e da Lei n. 6.385, de 7 de dezembro de 1976, e estende às sociedades de grande porte disposições relativas à elaboração e divulgação de demonstrações financeiras. Diário Oficial, República Federativa do Brasil, Brasília, DF, v. 134, n. 249-A, 28 dez. 2007. Seção 1 - Edição Extra. Retrieved from http://www.planalto. gov.br/ccivil_03/_ato2007-2010/2007/lei/111638.htm

Lei n. 11.941, de 27 de maio de 2009. (2009). Conversão da Medida Provisória n. 449 de 03/12/2008 em Lei. Altera a legislação tributária federal relativa ao parcelamento ordinário de débitos tributários; concede remissão nos casos em que especifica; institui regime tributário de transição. Diário Oficial, República Federativa do Brasil: Brasília, DF, 2008. Retrieved from http://www.planalto.gov.br/ccivil_03/_ato2007-2010/2009/lei/ 111941.htm

Lev, B., \& Nissim, D. (2004). Taxable income, future earnings, and equity values. The Accounting Review, 79(4), 1039-1074. doi 10.2308/accr. 2004.79. 4.1039

Lopes, A. B., \& Walker, M. (2008). Firm-level incentives and the informativeness of accounting reports: an experiment in Brazil. Retrieved from http://ssrn.com/abstract=1095781. doi 10.2139/ssrn. 1095781

Louza, A., Cunha, M. F., Iara, R. N., \& Rech, I. J. (2014). Custo de capital próprio no Brasil: Análise das premissas adaptadas a países emergentes. Proceeding of the Anpcont, Rio de Janeiro, RJ, Brazil, 8.

Martins, E., Martins, V. A., \& Martins, E. A. (2007). Normatização contábil: Ensaio sobre sua evolução e o papel do CPC. Revista de Informação Contábil, $1(1), 7-30$. 
Medida Provisória n. 449, de 3 de dezembro de 2008. (2008). Altera a legislação tributária federal relativa ao parcelamento ordinário de débitos tributários, concede remissão nos casos em que especifica, institui regime tributário de transição, e dá outras providências. Diário Oficial, República Federativa do Brasil: Brasília, DF, 2008. Retrieved from http://www.planalto.gov.br/ ccivil_03/_ato2007-2010/2008/mpv/449.htm

Myers, S. (1984). The capital structure puzzle. Journal of Finance, 39(3), 574-592. doi 10.3386/w1393

Myers, S. C., Majluf, N. S. (1984). Corporate financing and investment decisions when firms have information that investors do not have. Journal of Financial Economics, 13, 187-221. doi 10.3386/w1396

Niyama, J. K. (2005). Contabilidade internacional. São Paulo: Atlas.

Osma, B. G., \& Pope, P. F. (2011). Strategic balance sheet adjustments under first-time IFRS adoption and the consequences for earnings quality. doi 10.2139/ssrn.1735009.

Rezaee, Z., Smith, M., \& Szendi, J. Z. (2010). Convergence in accounting standards: insights from academics and practitioners. Advances in Accounting, 26(1), 142-154. doi 10.1016/j.adiac.2010.01.001

Tang, T. (2006). Book-tax differences: A function of accounting-tax misalignment, earnings management and tax management: empirical evidence from China. American Accounting Association Annual Meeting, 2006, Washington. doi 10.2139/ssrn.872389

Teixeira, E. A., Nossa, V., \& Funchal, B. (2011). O índice de sustentabilidade empresarial (ISE) e os impactos no endividamento e na percepção de risco. Revista de Contabilidade e Finanças, 55(22), 29-44. doi 10.1590/S1519-7077 2011000100003

Treasury (2012). The President's Framework for Business Tax Reform. US Department of the Treasury. pp. 1-25.

Whitaker, C. (2005). Bridging the book-tax accounting gap. The Yale Law Journal, 115(1), 680-726.

\section{ABOUT THE AUTHORS}

\section{MARIANA TITOTO MARQUES}

Master degree student in Controlling and Financial Accounting for the Department of Accounting, Universidade de São Paulo.

Avenida dos Bandeirantes, 3900, Monte Alegre - Ribeirão Preto - SP - Brasil - CEP 14040-900 E-mail: marianatitoto@gmail.com 


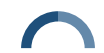

Mariana Titoto Marques, Silvio Hiroshi Nakao e Patrícia de Souza Costa

\section{SILVIO HIROSHI NAKAO}

$\mathrm{PhD}$ in Controlling and Financial Accounting from the Department of Accounting, Universidade de São Paulo.

Associate Professor at the Department of Accounting, Universidade de São Paulo.

Avenida dos Bandeirantes, 3900, Monte Alegre - Ribeirão Preto - SP - Brasil - CEP 14040-900

E-mail:shnakao@usp.br

\section{PATRÍCIA DE SOUZA COSTA}

$\mathrm{PhD}$ in Controlling and Financial Accounting from the Department of Accounting, Universidade de São Paulo.

Assistant Professor at the Department of Accounting,

Universidade Federal de Uberlândia.

João Naves de Ávila, 2121, Santa Mônica - Uberlândia - MG - Brasil - CEP 38400-902

E-mail: patriciacosta_1@yahoo.com.br 